\title{
Effects of Microwave Radiation on Human Brain: The Positives and Negatives
}

\author{
Ela Bhattacharya, Mohanchandra Mandal, and Dipasri Bhattacharya
}

\begin{abstract}
Several RF sources are present for the commercial as well as defense application. In this article we will focus on the neurological consequences of Microwave Radiation (MWR). Since microwaves impact so many facets of our lives, this research focuses on their health implications. The brain is perhaps the most sensitive organ to MWR, with mitochondrial damage manifesting faster and more profoundly than in other regions. The effects of MWR on brain metabolic pathways have piqued public attention. The possibility for significant numbers of people to be subjected to dynamic, multi-frequency microwave energy nowadays, is a reality. Many urban people residing in the highrise structures of the city, come in the main beam radiation of the antenna which is mounted at a comparable height. Owing to the pervasive presence of MWR, its extensive usage, and the potential for harmful effects, comprehensive analyses of the health risks are imperative. It is crucial, therefore, to assess the level of exposure that is safe for the general population so as to minimize adverse effects despite reducing the favorable uses of microwaves.
\end{abstract}

Keywords- EM spectrum, Radiation, Microwave, Neurological hazards

\section{INTRODUCTION}

The electromagnetic (EM) spectrum, as we all know, encompasses all kinds of EM radiation. Radiation is a form of energy that flows and disperses as it does so. EM radiation can take many types, including visible light from a lamp in your home or radio waves from a radio station. The EM spectrum starts all the way from DC, $3 \mathrm{kHz}$, it goes to a few THz. From the application point of view, at extremely low frequencies of the spectrum, the sources are, basically earth and subways. After that, the power outlets: $50 \mathrm{~Hz}$ AC capacity in India and $60 \mathrm{~Hz}$ in the USA, find its place in the EM spectrum. Next comes AM FM radio; AM radio frequency is from 530 to $1620 \mathrm{KHz}$ and then FM radio which ranges from $88 \mathrm{MHz}$ to $108 \mathrm{MHz}$, followed by TV transmission [1]. Beyond that, microwaves work at $2.45 \mathrm{GHz}$ including Wi-Fi, which works from 2.4 to $2.483 \mathrm{GHz}$. EM radiations are classified into 2 zones- one is known as a nonionizing zone, and another is known as an ionizing zone. There's far more energy in ionizing radiation, given by the formula $E=h f$, where $f$ is frequency. So, the higher the frequency, the higher the energy would be. So, it can sever the molecular bond and is thus referred to as ionizing radiation. The microwave frequency, essentially has a lower frequency and therefore, has lower energy. Energy, however, is not only defined by $E=h f$; energy also equals power multiplied by time. Therefore, if power is greater, less time will be needed and if the power is lower, the task can take longer to do. In order to focus on the detrimental effects of MWR, let us consider an instance. There are AM towers where the standard frequency range is from 530 to $1620 \mathrm{kKz}$ and these AM towers can transmit approximately, 100

\section{ISSN: 2736-576X}

DOI: http://dx.doi.org/10.24018/ejers.2022.7.1.2650

Published on January 15, 2022.

Ela Bhattacharya, School of Electrical Sciences,Indian Institute of Technology Bhubaneswar, India (e-mail: eb10@iitbbs.ac.in).

Mohanchandra Mandal, IPGME\&R and SSKM Hospital, Kolkata, India.

Dipasri Bhattacharya, R. G. Kar Medical College and Hospital, Kolkata, India.
$\mathrm{KW}$ of power up to even $1 \mathrm{MW}$ of power. The telecommunication authorities, however, take care and there is at least no residential building or complex within a $1 \mathrm{~km}$ radius. They know, therefore, that such actions cause a health hazard, and therefore they take that precaution. Microwave devices, on the other hand, operates between $300 \mathrm{MHz}$ to $300 \mathrm{GHz}$. There are airports, railway stations, universities, schools and numerous Wi-Fi-enabled facilities. Also, there are plans to build cities with Wi-Fi. This, in fact, can also create a lot of health issues for several individuals. Several technologies in India operate in $800 \mathrm{MHz}$-band including CDMA, GSM at $900 \mathrm{MHz}$, then GSM at $1800 \mathrm{MHz}$, then we have $3 \mathrm{G}$ and $4 \mathrm{G}$. 3G-operators in India are allowed to transmit $20 \mathrm{~W}$ of power An additional concession is given to a $4 \mathrm{G}$ operators; they can transmit up to $40 \mathrm{~W}$ of power and consequently there are more than 6 lakh towers in India.

\section{SPECIFIC ABSORPTION RATE AND ITS IMPACT}

\section{A. Specific Absorption Rate}

Let us consider a case where it goes to the nearest base station where a mobile phone propagates $1 \mathrm{~W}$ of power and that base station actually transmits $20 \mathrm{~W}$ of power to communicate with this same cell phone.Then, via a switching network, this base station (say, BS1). In fact, the Specific Absorption Rate (SAR) value of the cell phone determines the radiation from the cell phone. It's limit has been set at $1.6 \mathrm{~W} / \mathrm{kg}$. However, the threshold was set in 1998 and this threshold was set at only 6 minutes per day use. So, the mobile phones that people use were originally planned for just 6 minutes of daily usage, communicates with some other base station (BS2), which transmits another $20 \mathrm{~W}$ of power to the cell phone, which transmits $1 \mathrm{~W}$ of power. So, for one mobile phone connection $1+20+20+1=42 \mathrm{~W}$ of power has been consumed. Surprisingly, the effective power used by cell phones as well as cell towers is only $0.0000001 \mathrm{~W}$, which means, $41.99999 \mathrm{~W}$ power is getting dissipated in the atmosphere. When a call is initiated, roughly one-third of the power is getting absorbed in the human body; specially if the cell phone is held erect against the ears, then one-third of the power is going towards the head. But as far as the cell towers are concerned, it affects people living in direct proximity.

\section{B. Effects of SAR}

The dose of the absorbed energy is measured in terms of Specific Absorption Rate (SAR), expressed in watts per kilogram (W/kg) of body weight. In fact, the SAR value of the cell phone determines the radiation from the device. In 1998, the limit (safety threshold) of SAR has been set at $1.6 \mathrm{~W} / \mathrm{kg}$ which translates into daily use of cell phone for only 6 minutes. So, the mobile phones that people use were originally planned for just 6 minutes of daily usage. By virtue of a safety margin of 3 to 4 times, a person should not use cell phone for more than 18 to 24 minutes per day. Thus, the lower the SAR value the better it would be. The typical SAR value may vary from $0.3 \mathrm{~W} / \mathrm{kg}$ to about $1.6 \mathrm{~W} / \mathrm{kg}$. Depending on the holding posture, there are chances that $90 \%$ of the radiation is going towards human body. It is of utmost importance to reduce the exposure to Radio Frequency (RF) energy. The RF electromagnetic fields have been classified as potential carcinogen (class 2B) in the factsheet released by the International Agency for Research on Cancer 
(IARC) [2], [3]. Scientists are recently, persuading WHO to make this scenario as class $2 \mathrm{~A}$ which is known as probable carcinogen or even class 1 , which is known human carcinogen [4]. Based on several epidemiological studies reporting about the incidence of leukaemia in children and brain tumours in adults after prolonged exposure to Magnetic Field (MF) of approximately, $0.4 \mu \mathrm{T}$, it has been speculated for many years that both residential and industrial exposures to extremely low frequency (ELF) MF may be a potential carcinogen. The carcinogenic potential of cellular communication systems has been determined to be limited to glioma [5].

\section{Positive Aspects of Microwave Radiation}

\section{A. Microwave Ablation Technique}

The charge switches signs almost 2 billion times a second $(9.2 \times$ $10^{8} \mathrm{~Hz}$ ) in a microwave oscillating at $9.2 \times 10^{8} \mathrm{~Hz}$. As a radiationinduced oscillating electric charge interacts with a water molecule, the molecule flips. To optimise this interaction, microwave radiation is tuned to the natural frequency of water molecules. The electrical charge on the water molecule flips back and forth 2-5 billion times a second as a result of the microwave energy impacting the molecules, depending on the frequency of the energy. The vigorous motion of water molecules enhances the temperature of water. Temperature is an indicator of how quickly molecules move in a medium.

Microwave ablation (MWA) is yet another minimally invasive cancer procedure. Ultrasound, computed tomography (CT), and magnetic resonance imaging (MRI) are all used by MWA to guide the placement of a specialised needle-like probe through a tumour. MWA uses microwaves to heat and dissolve tumours. MWA is a low-risk procedure with a shorter hospital stay for the patient. Many tumours may be treated by ablation at the same time. When a new cancer develops, the treatment should be replicated. It is necessary to use a straight needle. The MW generator produces EM waves in the MW energy spectrum. It is bound to the needles by insulated wires. In certain patients with liver cancers that are unsuitable for surgical resection, MWA may be a successful therapy for primary liver cancer and cancers that have metastasized to liver. Similar argument is applicable to lung tumors. This therapy of MWA can be extended to the treatment of brain tumours as well. More than half of liver tumours treated with ablation have not recurred in most studies. Tiny liver tumours can be entirely removed with a success rate of more than $85 \%$. Significant treatment-related complications are uncommon, and the trauma is less than that of surgery. Ablation can be used to combat chronic liver cancers on a regular basis. There is no need for a surgical incision-only a slight nick in the skin that does not require stitches. The amount of tumour tissue that can be removed by ablation is limited. This is due to current equipment constraints.

\section{B. Detection of Brain Strokes using Microwave Tomography (MWT)}

In developed countries, cerebrovascular injuries (CVAs) are one of the leading causes of physical disability and mortality in adults. Ischemic or cerebral infarction (85\% of cases) and hemorrhagic CVAs (or strokes) are the two forms of CVAs (or strokes) (15 percent ). The extent of the stroke must be determined. In order to implement the appropriate treatment, it must be assessed quickly. Strokes induce alterations in the dynamic electric permittivity of brain tissues, which can be detected using microwave tomography, according to recent research in biomedical imaging. MRI or CT imaging are now the only ways to distinguish the type of stroke. However, these cumbersome and costly frameworks necessitate too much infrastructure to be used outside of the hospital. A microwave imaging system with 24 antennas was created recently [6] for evaluating an algorithm based on the Truncated Singular Value Decomposition scheme [7], and a previous analysis on 2-D phantoms used the linear sampling approach for brain stroke monitoring [7]. In the microwave frequency spectrum, recent studies have shown that complex permittivity is dependent on the type of stroke (ischemic or hemorrhagic). Indeed, complex dielectric permittivity increases by up to $20 \%$ in the hemorrhagic stroke region [8], whereas it decreases by $10 \%$ in the ischemic stroke area [8], [9]. Because of their intrinsic contrast mechanism, low cost, and short acquisition time, microwave imaging techniques are quite a promising form of stroke classification [10]. EMTensor GmbH (Vienna, Austria) has developed a compact microwave scanner for stroke detection and management [11], which can be integrated into ambulances. MWT could present a better, portable and cost-effective alternative to existing imaging techniques for non-invasive examination of acute and chronic functional and pathological problems of soft tissues. MWT was stunted for a variety of technological reasons, including the high prices of specialized hardware modules and an inadequate processing capacity. Huge progress has been made in recent years. Over recent years, remarkable advancements in both communication technology (mobile) and computation have launched unique possibilities for MWT research and innovation in clinical and therapeutic applications. Biological tissues are distinguished in the microwave spectrum and can thus be imaged based on their dielectric properties. The safety aspect of MWT imaging is crucial. In comparison to CT imaging and nuclear medicine, which use ionising radiation, this modality uses a non-ionizing electromagnetic (EM) field. Applications of MWT includes: radiology of the extremities, breast cancer screening, lung cancer diagnostics, brain imaging, and cardiac imaging. It was discovered in the 1980s and 1990s that malignant tumours and healthy tissues possess different dielectric properties [12]-[15]. This principle is used in identifying the stroke area by MWT.

\section{Negative Aspects OF MicrowaVE RAdiATION}

\section{A. Related Articles on Brain Dysfunction}

In the present article, various studies reporting the effects of MWR on the brain (especially the hippocampus) have been scrutinized. The present article has focused on recent advances in this arena and encompasses the reviews of epidemiology, anatomy, electroencephalograms, learning and memory capabilities and the dynamics substantive to cognitive impairments. In broadcasting, the applications of microwaves are primarily TV broadcasting antennae and FM radio, that emit frequencies ranging between 80 and $800 \mathrm{MHz}$. Microwaves are created in telecommunications as a result of the proliferation of mobile phones and their associated base stations and microwave links. Microwaves are found in cordless phones, terrestrial trunked radios, blue-tooth services, and wireless local area networks (LANs). Various experiments have been undertaken to examine the effect of electronic networking technologies on humans, but only a few have identified a statistical correlation between cell phones and brain tumours. Those that are used to using a mobile phone ipsilaterally have a two-fold elevated chance of developing brain tumours relative to those who do not $[16]-[18]$. In a particular study group examining the risk of glioma and acoustic neuroma according to age at first exposure to mobile phones, the highest odds ratios was found among those first exposed before age 20 years [19]. Many other studies haven't yet endorsed the inference that brain tumors can be caused from mobile phone usage $[20]-[24]$. Yet another study conducted by the Interphone study group [25] concluded that the risk of malignant tumours like glioma or meningioma in mobile phone users did not increase. Gliomas are not present in the most exposed regions of the brain, according to new research by Larjabaara et al. [26]. There were 347 cases of melanoma in the head and neck region, as well as 1184 controls, in this study. Hardell et al. [27| analyzed the usage of cell and cordless phones and observed no significant risk. Dasdag et al. [28] examined personnel working at a TV transmitting station with a frequency spectrum of 202-209 $\mathrm{MHz}, 694-701 \mathrm{MHz}, 750-757 \mathrm{MHz}$, or 774-781 MHz and mediumband broadcast station. Questionnaires on their health conditions were issued to the workers. The latter showed that symptoms including stress, fatigue, headaches and sleeplessness were experienced. To maintain vital functions, the brain needs a high supply of oxygen and energy intake. As a consequence, non-harmful stimuli such as 
ionising radiation and hypoxia can impair this organ [29], |30|. MWR destroys hippocampal structures in rats, impaired cognitive potentiation, lowers neurotransmitter concentrations, decreases the amount of synaptic vesicles, and causes memory impairment, according to certain research communities [31].The long-term risks from radiofrequency radiation (RFR) exposure from mobile phones appears to be high in children owing to their rapid growth rates and greater vulnerability of nervous system. The increasing use of mobile phones in children, a form of addictive behaviour, has been associated with emotional and behavioural disorders [32]. In a study involving 13,000 mothers and children, it was found that prenatal exposure to mobile phones was associated with behavioural problems and hyperactivity in children. [33] In a Danish study involving 24,499 children, the emotional and behavioural difficulties at age of 11 years among children was noted to be higher (23\% increased Odds) in children whose mothers reported any mobile phone use at age 7 years compared with children whose mothers reported no use of mobile phones at age of 7 years. [34] A recent cross-sectional multicentric (20 study sites) study in US involving 4,524 children aged 8-11 years indicates that shorter screen time and longer sleep periods independently improves cognitive function. [35] Another recent study also indicates about the potential adverse effect of RFR on adolescents' cognitive functions. Interestingly, this impairment of cognitive function includes the spatial memory related to the brain regions which are exposed during mobile phone use. [36] Exposures to various non-thermal microwave EMF can adversely affect with diverse neuropsychiatric problems including depression. [37] In a comprehensive literature review, Pall ML states that "Wi-Fi causes oxidative stress, sperm/testicular damage, neuropsychiatric effects including EEG changes, apoptosis [cell death], cellular DNA damage, endocrine changes, and calcium overload,". [38] Furthermore, these effects from continuous, long-term exposure may be cumulative, and that pulsed signals are more biologically active than a smooth carrier wave. Different study have reported variable effect of exposure to RFEMF in the vicinity of short-wave broadcast transmitter on the sleep parameters ranging from prevalence of difficulties in the initiation and maintenance of sleep [39] to no effect [40]. Studies evaluating sleep quality among humans exposed to extremely low frequency electromagnetic field (ELF-EMF) have not reached to any conclusive evidence [41]. A recent study conforms with the lack of overall effects on sleep architecture, well-being, cognitive function and clinically considerable effects on sleep by RF-EMF similar to those emitted by $3 \mathrm{G}$ mobile phones [42], [43]. However, in the same study a reduction of sigma-1 power spectrum was observed which might have implications on long-term sleep quality. [44] Contradictory outcomes have been reported in literature owing to methodological limitations and hence no final conclusions can be drawn about the potential effect of microwaves on sleep. Brain deterioration and structural damage are two of the detrimental effects of MWR on the brain. According to an epidemiological review, MWR induces human exhaustion, headaches, excitement, dreams, memory loss, and other neurasthenia symptoms [45]. A cross-sectional study designed to detect neurobehavioural disorders among the residents living in the vicinity of base stations and are exposed to radiofrequency-electromagnetic field (RF-EMF) found that the prevalence of neuropsychiatric complaints such as memory problems, headache, sleep disturbances, depressive attitude, dizziness etc were considerably more among the exposed individuals compared with the controls. [46] In a cross-sectional communitybased study in Singapore involving people using hand-held mobile phone, headache was found to be the most prevalent central nervous system symptoms compared with the nonusers; the prevalence of headache increased further with increased duration of usage per day. [47] Several studies have identified a correlation between exposure to ELF-EMFs and the onset of Alzheimer's disease [48], [49] though their physiological nexuses are uncertain. One speculation is RF-EMF induced biochemical modifications, oxidative stress and ROS generation which is involved mainly in neurodegenerative disorders such as Alzheimer disease, Huntington disease, and Parkinson disease. This can also be associated with induction of several neuropsychiatric disorders, including anxiety disorders, depression, impairment of emotional and mental well-being [50], [51].

\section{B. Adverse effects of MWR on neurological activity: Mecha- nism of Action}

The adverse effects of electromagnetic field (EMF) are assumed to be indirect effects of several biochemical modifications. Thermal and Nonthermal interactions, oxidative stress, decrease in melatonin secretion, disturbances in calcium ion efflux/influx and thereby influencing cAMP pathway and serotonin/melatonin conversion and their efflux from the cells of pineal gland-are some of the proposed mechanisms. [52] The interaction with NADH oxidase in the plasma membrane leads to formation of reactive oxygen species (ROS) which activate the matrix metalloproteinases. This causes activation of ERK cascade (one of the four mitogen-activated protein kinase signalling cascades) which adversely affects the cell cycle progression, apoptosis, differentiation and metabolism in a complex manner. [53] Among all, the oxidative stress and ROS generation appears to be the most important mechanism for damage to DNA, protein and lipids [54]. The brain shows high metabolic rate and high oxygen intake but has poor energy stores. The brain has the highest need for oxygen in the human body and hence it is vulnerable to any disruptions in energy metabolism owing to ionizing radiation and hypoxia. It is said that the nervous system is practically helpless to ROS insults owing to its high metabolic rate, inadequate oxidant protection and reduced cellular turnover. [54] The primary site for Oxidative Phosphorylation and Adenosine Triphosphate (ATP) synthesis is mitochondria. The respiratory chain's redox enzymes an d coenzymes are found in close proximity to the inner mitochondrial membrane. Mitochondria play a variety of roles in the body, including apoptosis regulation and $\mathrm{Ca}^{2+}$ storage, in addition to energy conversion. Mitochondria are both the initiating point and the target of several signaling pathways. Neurons are intrinsically very responsive to a decrease in ATP supply. Mitochondria, as the body's primary source of energy, are vulnerable to MWR damage. Succinate De-Hydrogenase (SDH) is one of the most important enzymes of mitochondrial energy metabolism. In animal model, the activity of SDH in rat hippocampus has shown to be decreased dramatically at 6 hours after radiation, culminating in alterations of mitochondrial energy metabolism. The terminal complex of mitochondrial electron transport chain, the Cytochrome $\mathrm{c}$ OXidase (COX), is embedded in the inner membrane of mitochondria [55]-[57]. COX activity has been reportedly inhibited by certain levels of MWR. The findings revealed that MWR has toxic effects on COX activity compounded over time and that there was a dosedependent correlation [56]. A mutation in the gene encoding the enzyme Copper-Zinc $\mathrm{Cu}^{2+} / \mathrm{Zn}^{2+}$ Superoxide dismutase (SOD) can alter the function of this antioxidant. This mutation (SOD1) has been found in about $20 \%$ of patients of Amyotrophic Lateral Sclerosis (ALS), a neurodegenerative condition that causes motor neurons in the spinal cord, motor cortex, and brainstem to degenerate progressively [58]. MWR alters the expression of genes that code for the respiratory chain, resulting in problems with brain energy metabolism. MWR has the potential to increase molecular rotation and vibration, as well as the frequency of collisions between molecules, causing chemical bonds to break and thus damage the mitochondrial membrane [59]. Secondly, MWR causes oxidative modification of biological macromolecules and mitochondrial damage by increasing intracellular reactive oxidative species (ROS) and disrupting antioxidant enzymes, resulting in oxidative modification of biological macromolecules and mitochondrial damage. Similar to X-rays, the exposure to microwave radiation can generate reactive oxygen species (ROS) [60]-[63]. Additionally, MWR activates phospholipases and proteases, which triggers intracellular $\mathrm{Ca}^{2+}$ overload and mitochondrial membrane damage [64]-|67]. MWR induced brain damage involves the phosphatidylinositol 3-kinase (PI3K)/Akt pathway.This is a pro-survival anti-apoptotic kinase signaling cascade which plays an important role for cellular survival [68], [69]. Akt is a serine/threonine protein kinase, also known as protein kinase $\mathrm{B}(\mathrm{PKB})$. This Akt is the primary 
protein effector situated downstream of the PI3K signalling pathway. Akt plays an important role in glucose metabolism by regulating the biological function of insulin [70]. Dysregulated PI3K/Akt pathway has been linked or incriminated with various carcinogenesis [71]. MWR can alter the expression or can cause structural damage of mitochondrial DNA. This results in decreased ATP production [72] In animal model, exposure to microwaves resulted in excessive activation of N-methyl-D-aspartate (NMDA) receptor signalling pathway. Thus the microwaves adversely affect the learning process and memory by modulating the hippocampal synaptic plasticity. Maternal exposure to microwaves may lead to numerous neurological effects in the baby [73]. Table I] summarizes the degrading effects of prolonged exposure to MWR.

\section{CONCLUSION}

In this field of study, considering the negative effects of MWR, the following problems are present: (a) The dosage, duration, and frequency of MWR-induced disruption of brain energy metabolism are all variables that need to be investigated further;(b) The longterm consequences of MW radiation-induced mitochondrial damage are unknown, and its connection to mitochondria-related neurodegenerative (ND) disorders like Alzheimer's disease warrants further investigation. The lack of uniform standards among laboratories creates a barrier to further growth and knowledge sharing. Many ND disorders, such as Parkinson's disease (PD), Alzheimer's disease (AD), Huntington's disease (HD), and Amyotrophic Lateral Sclerosis (ALS), are caused by ND mechanisms, and many of them are known as pathologies because of protein aggregation. Several reports seem to point to a connection between MWR exposure and occupational health but it still requires more conclusive results.

On the positive side, several technological advancements will possibly allow for the treatment of larger tumours in the future using MWA. Ablation is as yet, incapable of destroying microscopic tumours or preventing cancer from recurring. In this article, we have also focused on microwave imaging to diagnose and identify strokes. The advantage of the hemorrhage's physical properties can be utilised. It includes a $10 \%$ improvement in permittivity on both real and imaginary components. Thus, in many aspects MWR proves to be very beneficial for life.

\section{REFERENCES}

[1] Kumar G. Cell Phone/Tower Radiation Hazards and Solutions. Mumbai, July-August 2013

[2] Kumar G and Kumar N. Report on Cell Tower Radiation. LAP LAMBERT Academic Publishing, Germany, 2016.

[3] IARC Monographs on the Identification of Carcinogenic Hazards to $\mathrm{Hu}-$ mans. Lyon (FR): International Agency for Research on Cancer; 1987-. Available from: https://www.ncbi.nlm.nih.gov/books/NBK294452/

[4] Kumar G. Cell Phone/Tower Radiation Hazards and Solutions. Mumbai, April-June 2014.

[5] Szmigielski S. Cancer risks related to low-level RF/MW exposures, including cell phones. Electromagn Biol Med. 2013;32:273-80.

[6] Scapaticci R, Bucci OM, Catapano I, Crocco L. Differential microwave imaging for brain stroke follow-up. Int. J. Antennas Propag. vol. 2014, 2014, Art. no. 312528.

[7] Scapaticci R, di Donato L, Catapano I, Crocco L. A feasibility study on microwave imaging for brain stroke monitoring. Prog. Electromagn. Res. B. 2012;40:305-324.

[8] Hopfer M, Planas R, Hamidipour A, Henriksson T, Semenov S. Electromagnetic tomography for detection, differentiation and monitoring of brain stoke. IEEE Antennas Propag. Mag. 2017;59(5):86-97.

[9] Semenov S, Huynh T, Williams T, Nicholson B, Vasilenko A. Dielectric properties of brain tissue at $1 \mathrm{GHz}$ in acute ischemic stroke: Experimental study on swine. Bioelectromagn. 2017;38(2):158-163.

[10] Coli VL, Tournier P-H, Dolean-Maini V, El Kanfoud I, Pichot C, et al.. Detection of Simulated Brain Strokes Using Microwave Tomography. IEEE Journal of Electromagnetics, RF and Microwaves in Medicine and Biology, IEEE, 2019;3(4):254- 260. doi: 10.1109/JERM.2019.2921076.

[11] Semenov S, Seiser B, Stoegmann E, Auff E. Electromagnetic tomography for brain imaging: From virtual to human brain. in Proc. IEEE Conf. Antenna Meas. Appl., Antibes Juan-les-Pins, 2014, pp. 1-4.
TABLE I

ADVERSE EFFECTS OF MWR

\begin{tabular}{|c|c|c|}
\hline Researchers & Dosage of MWR & Results \\
\hline $\begin{array}{l}\text { Xie et al. } \\
[55], \mid 79]\end{array}$ & $\begin{array}{l}\text { Exposed male Wistar } \\
\text { rats, MWR ( } 3 \text { and } \\
\left.30 \mathrm{~mW} / \mathrm{cm}^{2} \text { for } 1 \mathrm{~h}\right)\end{array}$ & $\begin{array}{l}\text { 1) Damaged mitochondria in } \\
\text { the } 30 \mathrm{~mW} / \mathrm{cm}^{2} \text { group, rest } \\
\text { unaffected. } \\
\text { 2) Ultrastructural changes in } \\
\text { the mitochondria were in- } \\
\text { duced within } 24 \mathrm{~h} \text { post } \\
\text { MWR exposure. } \\
\text { 3) Post MWR of } 30 \mathrm{~mW} / \mathrm{cm}^{2} \\
\text { for } 0,3 \text { and } 24 \mathrm{~h} \text {, decreased } \\
\text { COX I mRNA expression in } \\
\text { the rat cerebral cortex and } \\
\text { hippocampus. }\end{array}$ \\
\hline $\begin{array}{l}\text { Xiong et al. } \\
\text { [56 }\end{array}$ & $\begin{array}{c}\text { MWR of } 30 \\
\mathrm{~mW} / \mathrm{cm}^{2} \text { on male } \\
\text { Wistar rats }\end{array}$ & $\begin{array}{c}\text { Decreased COX activity and } \\
\text { Reduced expression of COX I/IV } \\
\text { mRNA and COX I protein were } \\
\text { found. }\end{array}$ \\
\hline $\begin{array}{l}\text { Zhao et al. } \\
\text { [57] }\end{array}$ & $\begin{array}{l}\text { Exposed male Wistar } \\
\text { rats, MWR }(30 \\
\mathrm{mW} / \mathrm{cm}^{2} \text {, duration: } \\
5 \mathrm{~min})\end{array}$ & $\begin{array}{l}\text { Mitochondrial ATP content in the } \\
\text { hippocampus dropped to the } \\
\text { lowest levels } 3 \mathrm{~d} \text { post MWR and } \\
\text { recovered by next } 7 \mathrm{~d} \text {. }\end{array}$ \\
\hline$\underset{[60]}{\text { Wang et al. }}$ & $\begin{array}{l}\text { Exposed monkeys, } \\
\text { MWR }\left(95 \mathrm{~mW} / \mathrm{cm}^{2}\right. \\
\text { and } 11 \mathrm{~mW} / \mathrm{cm}^{2} \text { for } \\
10 \mathrm{~s} \text { and } 4.68 \\
\mu \mathrm{W} / \mathrm{cm}^{2} \text { for } 12 \mathrm{~h} / \mathrm{d} \\
\text { for } 30 \mathrm{~d} \\
\text { cumulatively) }\end{array}$ & $\begin{array}{l}\text { Abnormalities in mitochondrial } \\
\text { function-related metabolites in } \\
\text { urine. }\end{array}$ \\
\hline $\begin{array}{l}\text { Zhao et al. } \\
\text { [61] }\end{array}$ & $\begin{array}{l}\text { Exposed male Wistar } \\
\text { rats, MWR }(2.5,5 \\
\text { and } 10 \mathrm{~mW} / \mathrm{cm}^{2}, \\
\text { with SAR of } 1.05 \text {, } \\
2.1 \text { and } 4.2 \mathrm{~W} / \mathrm{kg}, \\
\text { respectively, for } 6 \\
\min / \mathrm{d} \text { for } 30 \mathrm{~d})\end{array}$ & $\begin{array}{l}\text { Mitochondria were swollen and } \\
\text { vacuolized with ultrastructural } \\
\text { changes due to the increasing } \\
\text { SAR. }\end{array}$ \\
\hline $\begin{array}{c}\text { Kesari et al. } \\
{[74]}\end{array}$ & $\begin{array}{l}\text { Exposed } 45 \text {-day-old } \\
\text { male Wistar rats, } 2 \\
\text { h/d for } 60 \mathrm{~d} \text { by } \\
\text { mobile phone }(3 \mathrm{G})\end{array}$ & $\begin{array}{l}\text { 1) Induced DNA strand breaks } \\
\text { in the brain. } \\
\text { 2) MWR induced apoptosis in } \\
\text { the brain by activation of } \\
\text { p38MAPK, the pathway of } \\
\text { principal stress response. }\end{array}$ \\
\hline $\begin{array}{l}\text { Xu et al. } \\
\text { [75] }\end{array}$ & $\begin{array}{l}\text { Exposed cortical } \\
\text { neurons of neonatal } \\
\text { rats to MWR }\end{array}$ & $\begin{array}{l}\text { Expression of mtTFA mRNA and } \\
\text { protein increased. }\end{array}$ \\
\hline $\begin{array}{l}\text { Lu et al. } \\
\text { [76] }\end{array}$ & $\begin{array}{c}\text { Exposed primary } \\
\text { cultures of glial cells } \\
\text { to } 2450 \mathrm{MHz} \text { MWR } \\
\left(4 \mathrm{~mW} / \mathrm{cm}^{2} \text { for } 2\right. \\
\mathrm{h} / \mathrm{d} \text { for } 3 \mathrm{~d})\end{array}$ & $\begin{array}{l}\text { An increased intracellular free } \\
\mathrm{Ca}^{2+} \text { was found. }\end{array}$ \\
\hline $\begin{array}{l}\text { Wang et al. } \\
\text { [77] }\end{array}$ & $\begin{array}{l}\text { Exposed Wistar rats, } \\
\text { MWR }(10,30 \text { and } \\
100 \mathrm{~mW} / \mathrm{cm}^{2} \text { for } 5 \\
\text { min, respectively) }\end{array}$ & $\begin{array}{l}\text { Reduced SDH activity which } \\
\text { recovered } 7 \mathrm{~d} \text { post MWR. }\end{array}$ \\
\hline $\begin{array}{l}\text { Sander et } \\
\text { al. }|78|\end{array}$ & $\begin{array}{l}\text { Exposed SD rats, } \\
\text { MWR with a } \\
\text { frequency of } 591 \\
\text { MHz }(13.8 \\
\left.\mathrm{mW} / \mathrm{cm}^{2}\right)\end{array}$ & $\begin{array}{l}\text { Reduced availability of ATP, } \\
\text { resulting in brain energy } \\
\text { metabolism disorders. }\end{array}$ \\
\hline $\begin{array}{l}\text { Dong et al. } \\
{[80]}\end{array}$ & $\begin{array}{l}\text { Exposed SD rats, } \\
\text { MWR }(4.68 \\
\mu \mathrm{W} / \mathrm{cm}^{2}, 12 \mathrm{~h} / \mathrm{d}, \\
\text { duration: } 30 \mathrm{~d})\end{array}$ & $\begin{array}{l}\text { Swelling and cavitation in the } \\
\text { mitochondria hippocampus and } \\
\text { cerebral cortex. }\end{array}$ \\
\hline
\end{tabular}


[12] Joines WT, Jirtle RL, Rafal MD, Schaefer DJ. Microwave power absorption differences between normal and malignant tissue. Int J Radiat Oncol Biol Phys. 1980 Jun;6(6):681-7. doi: 10.1016/0360-3016(80)90223-0. PMID: 7451273.

[13] Smith SR, Foster KR, Wolf GL. Dielectric properties of VX-2 carcinoma versus normal liver tissue. IEEE Trans Biomed Eng. 1986 May;33(5):522-4. doi: 10.1109/TBME.1986.325740. PMID: 3710509.

[14] Chaudhary SS, Mishra RK, Swarup A, Thomas JM. Dielectric properties of normal \& malignant human breast tissues at radiowave \& microwave frequencies. Indian J Biochem Biophys. 1984 Feb;21(1):76-9. PMID: 6490065.

[15] Morimoto T, Kimura S, Konishi Y, Komaki K, Uyama T, Monden Y, Kinouchi Y, Iritani T. A study of the electrical bioimpedance of tumors. J Invest Surg. 1993 Jan-Feb;6(1):25-32. doi: 10.3109/08941939309141189. PMID: 8452822.

[16] Kan P, Simonsen SE, Lyon JL, Kestle JR. Cellular phone use and brain tumor: a meta-analysis. J Neuro-Oncol. 2008;86:71-8.

[17] Khurana VG, Teo C, Kundi M, Hardell L, Carlberg M. Cell phones and brain tumors: a review including the long-term epidemiologic data. Surg Neurol. 2009;72:205-14.

[18] Myung SK, Ju W, McDonnell DD, Lee YJ, Kazinets G, Cheng CT, et al. Mobile phone use and risk of tumors: a meta-analysis. J Clin Oncol. 2009;27:5565-72.

[19] Hardell L, Carlberg M. Mobile phone and cordless phone use and the risk for glioma - Analysis of pooled case-control studies in Sweden, 1997-2003 and 2007-2009. Pathophysiology. 2015 Mar;22(1):1-13. doi: 10.1016/j.pathophys.2014.10.001. PMID: 25466607

[20] Johansen C, Boice JD, McLaughlin JK, Olsen JH. Cellular telephones and cancer-a nationwide cohort study in Denmark. J Natl Cancer Inst. 2001;93:203-7.

[21] Muscat JE, Malkin MG, Thompson S, Shore RE, Stellman SD, McRee D, et al. Handheld cellular telephone use and risk of brain cancer. JAMA. 2000;284:3001-7.

[22] Lönn S, Ahlbom A, Hall P, Feychting M. Long-term mobile phone use and brain tumor risk. Am J Epidemiol. 2005;161:526-35.

[23] Frei P, Poulsen AH, Johansen C, Olsen JH, Steding-Jessen M, Schüz $\mathrm{J}$. Use of mobile phones and risk of brain tumours: update of Danish cohort study. BMJ. 2011;343:522-4.

[24] Schüz J, Jacobsen R, Olsen JH, Boice JD, McLaughlin JK, Johansen C. Cellular telephone use and cancer risk: update of a nationwide Danish cohort. J Natl Cancer Inst. 2006;98:1707-13.

[25] Interphone study group. Brain tumour risk in relation to mobile telephone use: results of the INTERPHONE international case-control study. Int J Epidemiol. 2010;39:675-94.

[26] Larjavaara S, Schüz J, Swerdlow A, Feychting M, Johansen C, Lagorio $\mathrm{S}$, et al. Location of gliomas in relation to mobile telephone use: a case-case and case-specular analysis. Am J Epidemiol. 2011;174:2-11.

[27] Hardell L, Carlberg M, Mild KH, Eriksson M. Case-control study on the use of mobile and cordless phones and the risk for malignant melanoma in the head and neck region. Pathophysiology. 2011;18:325-33.

[28] Dasdag S, Balci K, Celik M, Batun S, Kaplan A, Bolaman Z, et al. Neurologic and biochemical findings and CD4/CD8 ratio in people occupationally exposed to RF and microwave. Biotechnol Biotechnol Equip. 1992;6:37-9.

[29] Balduini W, Carloni S, Buonocore G. Autophagy in hypoxia-ischemia induced brain injury. J Matern Fetal Neonatal Med. 2012;1:30-4.

[30] Greene-Schloesser D, Robbins ME, Peiffer AM, Shaw EG, Wheeler KT, Chan MD. Radiation-induced brain injury: A review. Front Oncol. 2012;2:73

[31] Zhao L, Peng RY, Wang SM, Wang LF, Gao YB, Dong J, et al. Relationship between cognition function and hippocampus structure after long-term microwave exposure. Biomed Environ Sci. 2012;25:182-8

[32] De-Sola Gutiérrez J, Rodríguez de Fonseca F, Rubio G. Cell-Phone Addiction: A Review. Front Psychiatry. 2016;7:175. doi: 10.3389/fpsyt.2016.00175.PMID: 27822187; PMCID: PMC5076301.

[33] Divan HA, Kheifets L, Obel C, Olsen J. Prenatal and postnatal exposure to cell phone use and behavioral problems in children. Epidemiology. 2008;19(4):523-9. doi: 10.1097/EDE.0b013e318175dd47. PMID: 18467962.

[34] Sudan M, Olsen J, Arah OA, Obel C, Kheifets L. Prospective cohort analysis of cellphone use and emotional and behavioural difficulties in children. J Epidemiol Community Health. 2016;70(12):1207-1213. doi: 10.1136/jech-2016-207419. PMID: 27217533.

[35] Walsh JJ, Barnes JD, Cameron JD, Goldfield GS, Chaput JP, Gunnell KE, et al. Associations between 24 hour movement behaviours and global cognition in US children: a cross-sectional observational study. Lancet Child Adolesc Health. 2018 Nov;2(11):783-791. doi:
10.1016/S2352-4642(18)30278-5. Epub 2018 Sep 27. PMID: 30268792; PMCID: PMC6298223

[36] Foerster M, Thielens A, Joseph W, Eeftens M, Röösli M. A Prospective Cohort Study of Adolescents' Memory Performance and Individual Brain Dose of Microwave Radiation from Wireless Communication. Environ Health Perspect. 2018;126(7):077007. doi: 10.1289/EHP2427. PMID: 30044230; PMCID: PMC6108834.

[37] Pall ML. Microwave frequency electromagnetic fields (EMFs) produce widespread neuropsychiatric effects including depression. J Chem Neuroanat. 2016 Sep;75(Pt B):43-51. doi: 10.1016/j.jchemneu.2015.08.001. PMID: 26300312

[38] Pall ML. Wi-Fi is an important threat to human health. Environ Res. 2018 Jul;164:405-416. doi: 10.1016/j.envres.2018.01.035. Epub 2018 Mar 21. PMID: 29573716.

[39] Abelin T, Altpeter E, Röösli M. Sleep disturbances in the vicinity of the short-wave broadcast transmitter Schwarzenburg. Somnologie. 2005; 9(4):203-209.

[40] Mohler E, Frei P, Fröhlich J, Braun-Fahrländer C, Röösli M; QUALIFEX-team. Exposure to radiofrequency electromagnetic fields and sleep quality: a prospective cohort study. PLoS One. 2012;7(5):e37455. doi: 10.1371/journal.pone.0037455. Epub 2012 May 18. PMID: 22624036; PMCID: PMC3356284.

[41] El-Helaly M, Abu-Hashem E. Oxidative stress, melatonin level, and sleep insufficiency among electronic equipment repairers. Indian J Occup Environ Med. 2010 Sep;14(3):66-70. doi: 10.4103/00195278.75692. PMID: 21461157; PMCID: PMC3062017.

[42] Barsam T, Monazzam MR, Haghdoost AA, Ghotbi MR, Dehghan SF. Effect of extremely low frequency electromagnetic field exposure on sleep quality in high voltage substations. Iranian $J$ Environ Health Sci Eng. 2012 Nov 30;9(1):15. doi: 10.1186/1735-2746-9-15. PMID: 23369281; PMCID: PMC3561068.

[43] Monazzam MR, Hosseini M, Matin LF, Aghaei HA, Khosroabadi H, Hesami A. Sleep quality and general health status of employees exposed to extremely low frequency magnetic fields in a petrochemical complex. J Environ Health Sci Eng. 2014 Apr 29;12:78. doi: 10.1186/2052336X12-78. PMID: 24904752; PMCID: PMC4045979.

[44] Lowden A, Nagai R, Åkerstedt T,Hansson Mild K, Hillert L. Effects of evening exposure to electromagnetic fields emitted by $3 \mathrm{G}$ mobile phones on health and night sleep EEG architecture. J Sleep Res. 2019;28:e12813.

[45] Jauchem JR. A literature review of medical side effects from radiofrequency energy in the human environment: involving cancer, tumors, and problems of the central nervous system. J Microw Power Electromagn Energy. 2003;38:103-23.

[46] Abdel-Rassoul G, El-Fateh OA, Salem MA, Michael A, Farahat F, El-Batanouny M, Salem E. Neurobehavioral effects among inhabitants around mobile phone base stations. Neurotoxicology. 2007 Mar:28(2):434-40. doi: 10.1016/j.neuro.2006.07.012. PMID: 16962663.

[47] Chia SE, Chia HP, Tan JS. Prevalence of headache among handheld cellular telephone users in Singapore: a community study. Environ Health Perspect. 2000 Nov;108(11):1059-62. doi: 10.1289/ehp.001081059. Erratum in: Environ Health Perspect 2001 Feb;109(2):A65. PMID:11102297; PMCID: PMC1240163.

[48] García AM, Sisternas A, Hoyos SP. Occupational exposure to extremely low frequency electric and magnetic fields and Alzheimer disease: a meta-analysis. Int J Epidemiol. 2008 Apr;37(2):329-40. doi: 10.1093/ije/dym295. Epub 2008 Feb 1. PMID: 18245151.

[49] Repacholi MH, Lerchl A, Roosli M, et al. Systematic review of wireless phone use and brain cancer and other head tumors. Bioelectromagnetics. 2012;33(3):187-206.

[50] Pizzino G, Irrera N, Cucinotta M, Pallio G, Mannino F, Arcoraci V, Squadrito F, Altavilla D, Bitto A. Oxidative Stress: Harms and Benefits for Human Health. Oxid Med Cell Longev. 2017;2017:8416763. doi: 10.1155/2017/8416763. PMID: 28819546; PMCID: PMC5551541.

[51] Salim S. Oxidative Stress and the Central Nervous System. J Pharmacol Exp Ther. 2017 Jan;360(1):201-205. doi: 10.1124/jpet.116.237503. PMID: 27754930; PMCID: PMC5193071.

[52] Aggarwal V, Tuli HS, Varol A, Thakral F, Yerer MB, Sak K, Varol M, Jain A, Khan MA, Sethi G. Role of Reactive Oxygen Species in Cancer Progression: Molecular Mechanisms and Recent Advancements. Biomolecules. 2019;9(11):735. doi: 10.3390/biom9110735. PMID: 31766246; PMCID: PMC6920770.

[53] Schieber M, Chandel NS. ROS function in redox signaling and oxidative stress. Curr Biol. 2014 May 19;24(10):R453-62. doi: 10.1016/j.cub.2014.03.034. PMID: 24845678; PMCID: PMC4055301.

[54] Sokolovic D, Djindjic B, Nikolic J, Bjelakovic G, Pavlovic D, Kocic G, Krstic D, Cvetkovic T, Pavlovic V. Melatonin reduces oxidative 
stress induced by chronic exposure of microwave radiation from mobile phones in rat brain. J Radiat Res. 2008 Nov;49(6):579-86. doi: 10.1269/jrr.07077. PMID: 18827438.

[55] Xie Y, Jiang HH, Gong XF, Zhang GB, Lu B, Xu Q, et al. Effects of microwave irradiation on mitochondrial cytochrome $\mathrm{C}$ oxidase subunits mRNA in rat brain. Acta Academiae Medicinae Militaris Tertlae. 2003;25:987-9

[56] Xiong L, Peng RY, Gao YB, Wang SM, Wang LF, Dong J, et al. Effects of AduoLa Fuzhenglin on changes of cytochrome c oxidase in rats' hippocampus after microwave exposure. Mil Med Sci. 2011;35:333-7

[57] Zhao L, Peng RY, Gao YB, Wang SM, Wang LF, Dong J, et al. Mitchondria morphologic changes and metabolic effects of rat hippocampus after microwave irradiation. Chin J Radiol Med Prot. 2007;27:602-4

[58] Julien, J.P., Kriz, J., 2006. Transgenic mouse models of amyotrophic lateral sclerosis. Biochim. Biophys. Acta 1762 (11-12), 1013-1024

[59] Wang Y, Sun HT, Wang BH, Zhang D. A study on thermal efficiency and non-thermal efficiency of microwave. Liaoning Chem Ind. 2006;35:167-9

[60] Wang LF, Li X, Peng RY, Gao YB, Zhao L, Wang SM, et al. A metabolomic approach to screening urinary metabolites upon microwave exposure in monkeys. Mil Med Sci. 2011;35:369-74

[61] Zhao L, Peng RY, Gao YB, Wang SM, Wang XM, Xu XP, et al. The changes of the COX gene expression in mitochondria in hippocampus of rats after exposure to microwave radiation. Chin J Phys Med Rehabil. 2009;30:31-3.

[62] Kesari KK, Kumar S, Behari J. 900-MHz microwave radiation promotes oxidation in rat brain. Electromagn Biol Med. 2011;30:219-34.

[63] Chen YM, Chen JY, Liu XH, Luo WJ, Wang Q, Xu H, et al. Effects of complementary zinc on antioxidase in brian of rats irradiated by microwave. J Fourth Mil Med Univ. 2005;26:444-6.

[64] Wang RY, Yang CL, Luo LH, Zhang JQ, Mu HL, Du P, et al. Oxidative stress effect of microwave radiation on mice brian. J Prev Med Chin PLA. 2013;31:292-4.

[65] Yang R, Peng RY, Gao YB, Wang SM, Hu WH, Xu XP, et al. The effect of microwaves on hippocampal neurons in vitro and its mechanism. Chin J Phys Med Rehabil. 2006;28:670-3.

[66] Lu MX, Nie JH, Zhu JQ, Qian C, Wang GH, Tong J. Biological effects of $2450 \mathrm{MHz}$ microwave combined with $\gamma$-rays on rat cultured gliacytes. J Radiat Res Raidat Process. 2010;28:172-6.

[67] Zuo HY, Lin T, Wang DW, Peng RY, Wang SM, Gao YB, et al. Neural cell apoptosis induced by microwave exposure through mitochondriadependent caspase-3 pathway. Int J Med Sci. 2014;11:426-35

[68] Sheppard K, Kinross KM, Solomon B, Pearson RB, Phillips WA Targeting PI3 kinase/AKT/mTOR signaling in cancer. Crit Rev Oncog. 2012;17:69-95.

[69] Prasad SS, Russell M, Nowakowska M. Neuroprotection induced in vitro by ischemic preconditioning and postconditioning: modulation of apoptosis and PI3K-Akt pathways. J Mol Neurosci. 2011;43:428-42.

[70] Meng XH, Chen B, Zhang JP. Intracellular Insulin and Impaired Autophagy in a Zebrafish model and a Cell Model of Type 2 diabetes. Int J Biol Sci. 2017 Jul 18;13(8):985-995. doi: 10.7150/ijbs.19249. PMID: 28924380; PMCID: PMC5599904.

[71] Zheng D, Zhu G, Liao S, Yi W, Luo G, He J, Pei Z, Li G, Zhou Y. Dysregulation of the PI3K/Akt signaling pathway affects cell cycle and apoptosis of side population cells in nasopharyngeal carcinoma. Oncol Lett. 2015 Jul;10(1):182-188. doi: 10.3892/ol.2015.3218. Epub 2015 May 18. PMID: 26170996; PMCID: PMC4487176.

[72] Guo, C., Sun, L., Chen, X., \& Zhang, D. (2013). Oxidative stress, mitochondrial damage and neurodegenerative diseases. Neural regeneration research, 8(21), 2003-2014. https://doi.org/10.3969/j.issn.16735374.2013.21.009

[73] Zhang, Y., Li, Z., Gao, Y., \& Zhang, C. (2015). Effects of fetal microwave radiation exposure on offspring behavior in mice. Journal of radiation research, 56(2), 261-268. https://doi.org/10.1093/jrr/rru097

[74] Kesari KK, Meena R, Nirala J, Kumar J, Verma HN. Effect of 3G cell phone exposure with computer controlled 2-D stepper motor on non-thermal activation of the hsp27/p38MAPK stress pathway in rat brain. Cell Biochemistry and Biophysics. 2014 Mar;68(2):347-358. DOI: 10.1007/s12013-013-9715-4. PMID: 23949848.

[75] Xu SC, Zhang L, Yu ZP, Zhong M. Effects of microwave exposure on Tfam expression in neurons and the relationship with energy metabolism disturbance. J Radiat Res Radiat Process. 2008;26:305-8

[76] Lu MX, Nie JH, Zhu JQ, Qian C, Wang GH, Tong J. Biological effects of $2450 \mathrm{MHz}$ microwave combined with $\gamma$-rays on rat cultured gliacytes. J Radiat Res Raidat Process. 2010;28:172-6
[77] Wang LF, Peng RY, Hu XJ, Gao YB, Ma JJ, Wang X, et al. Studies on the influence of high power microwave radiation on energy metabolism of brian in rats. Chin J Radiol Health. 2006;15:269-71

[78] Sanders AP, Joines WT. The effects of hyperthermia and hyperthermia plus microwaves on rat brain energy metabolism. Bioelectromagnetics. 1984;5(1):63-70. doi: 10.1002/bem.2250050107. PMID: 6712750.

[79] Xie Y, Jiang HH, Gong QF, Zhang GB, Yu JH, Yu ZP. [Effect of microwave irradiation on neurocyte mitochondrial ultrastructure and mtTFA mRNA expression in rats cerebral cortex and hippocampus. Zhonghua Lao Dong Wei Sheng Zhi Ye Bing Za Zhi. 2004 Apr;22(2):104-7. Chinese. PMID: 15130438.

[80] Dong J, Peng RY, Wang SM, Gao YB, Wang LF, Zhao L, et al. Effects on abilities of learning and memory and structural changes of brain in rats induced by microwave radiation under different conditions. Mil Med Sci. 2011;35:347-50 